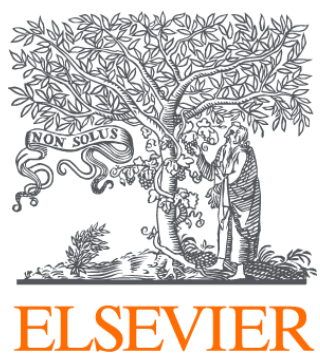

Since January 2020 Elsevier has created a COVID-19 resource centre with free information in English and Mandarin on the novel coronavirus COVID-

19. The COVID-19 resource centre is hosted on Elsevier Connect, the company's public news and information website.

Elsevier hereby grants permission to make all its COVID-19-related research that is available on the COVID-19 resource centre - including this research content - immediately available in PubMed Central and other publicly funded repositories, such as the WHO COVID database with rights for unrestricted research re-use and analyses in any form or by any means with acknowledgement of the original source. These permissions are granted for free by Elsevier for as long as the COVID-19 resource centre remains active. 
Letter to the Editor

\title{
Early detection of SARS-CoV-2 infection cases or outbreaks at nursing homes by targeted wastewater tracking
}

\author{
Laura Davó ${ }^{1}$, Raimundo Seguí ${ }^{1}$, Pilar Botija ${ }^{2}$, María José Beltrán ${ }^{3}$, Eliseo Albert ${ }^{4}$, \\ Ignacio Torres ${ }^{4}$, Pablo Ángel López-Fernández ${ }^{5}$, Rafael Ortí ${ }^{5}$, Juan Francisco Maestre ${ }^{1}$, \\ Gloria Sánchez ${ }^{6, \dagger}$, David Navarro ${ }^{4,7, *, \dagger}$ \\ 1) Global Omnium, Valencia, Spain \\ 2) Dirección de Atención Primaria, Departamento de Salud Clínico-Malvarrosa, Hospital Clínico Universitario de Valencia, Valencia, Spain \\ 3) Dirección de Enfermería, Departamento de Salud Clínico-Malvarrosa, Hospital Clínico Universitario de Valencia, Valencia, Spain \\ ${ }^{4)}$ Microbiology Service, Clinic University Hospital, INCLIVA Health Research Institute, Valencia, Spain \\ 5) Department of Preventive Medicine and Quality Assurance, Clinic University Hospital, INCLIVA Health Research Institute, Valencia, Spain \\ 6) Food Safety and Preservation Department, Institute of Agrochemistry and Food Technology (IATA-CSIC), Valencia, Spain \\ 7) Department of Microbiology, School of Medicine, University of Valencia, Valencia, Spain
}

\section{A R T I C L E I N F O}

\section{Article history:}

Received 15 January 2021

Received in revised form

6 February 2021

Accepted 7 February 2021

Available online $\mathrm{xxx}$

Editor: L. Leibovici

\section{To the Editor,}

Nursing homes (NH) have been severely affected by the coronavirus disease 2019 (COVID-19) pandemic, largely due to their congregate nature and the vulnerability of residents [1]. Advanced age, frailty and concurrence of underlying chronic health conditions place $\mathrm{NH}$ residents at high risk for developing severe forms of COVID-19 and for death. Long-lasting virus shedding of severe acute respiratory syndrome coronavirus 2 (SARS-CoV-2) in urine and faeces has been documented in both symptomatic and asymptomatic infected adults [2]. As a result, near-source tracking in the sewers serving particular buildings (i.e. campus dormitories, workplaces, correctional facilities, schools) has emerged as an appealing non-invasive tool that, when combined with subsequent targeted population screening when SARS-CoV-2 is detected, may enable rapid identification and control of facility outbreaks [3]. In

\footnotetext{
* Corresponding author: David Navarro, Microbiology Service, Clinic University Hospital, INCLIVA Health Research Institute, Valencia, Spain.

E-mail address: david.navarro@uv.es (D. Navarro).

Gloria Sánchez and David Navarro contributed equally to the present work.
}

this pilot study, we provide evidence demonstrating the feasibility and utility of this wastewater-based epidemiological approach for early identification of isolated cases or outbreaks of SARS-CoV-2 infection in $\mathrm{NH}$.

This study involved five $\mathrm{NH}$ facilities (listed as A to E) located in northeast Valencia (Spain), affiliated to the Clínico-Malvarrosa Health Department. These are nursing or mixed nursing/care homes, altogether providing care for 472 residents attended by 309 staff (Table 1). Selection from among the $17 \mathrm{NH}$ supported by the Clínico-Malvarrosa Health Department was based upon two criteria: (a) existence of one (NH A,B,C and D) or more (NH E, $n=4$ ) sewer manholes allegedly not shared with nearby buildings and (b) personal autonomy of most residents. Permission to analyse the wastewater was granted by the $\mathrm{NH}$ operator and the local authority responsible for the sewer system. $\mathrm{NH}$ sewage drain(s) were monitored for presence of SARS-CoV-2 RNA by testing near-source wastewater samples at least 5 days per week from 7 October to 28 December 2020. Grab samples were collected on site from water outlets at each facility. All samples were taken early in the morning, collecting $1 \mathrm{~L}$ of water in sterile plastic containers with sodium thiosulphate (VWR International, Radnor, PA, USA). Refrigerated water samples were transferred to the Global Omnium laboratory (Valencia, Spain), and concentrated within $24 \mathrm{~h}$ using the aluminium adsorption-precipitation method. Spiked Mengovirus (vMCO CECT 100000) acted as an internal control. Viral extraction from wastewater concentrates and RT-qPCR were performed as previously described $[4,5]$. The results are reported as genome copies (GC)/L. The limit of detection of the RT-qPCR assay was 670 GC/L.

As shown in Table 1, SARS-CoV-2 RNA was detected in wastewater samples collected from four out of the five $\mathrm{NH}(\mathrm{A}, \mathrm{B}, \mathrm{D}, \mathrm{E})$. The dynamics of SARS-CoV-2 RNA detection and viral loads measured at each $\mathrm{NH}$ are depicted in the Supplementary material 
Table 1

Detection of SARS-CoV-2 in wastewater, residents and staff at nursing homes included in the study

\begin{tabular}{|c|c|c|c|c|c|c|c|}
\hline $\begin{array}{l}\text { Nursing home (no. } \\
\text { of residents/no. of } \\
\text { staff) }\end{array}$ & Surveillance period & $\begin{array}{l}\text { Date of first } \\
\text { detection of SARS- } \\
\text { CoV-2 RNA in } \\
\text { wastewater }{ }^{a} / \text { day at } \\
\text { which peak RNA } \\
\text { levels }\left(\log _{10} \text { GC/L) }\right. \\
\text { was reached }\end{array}$ & $\begin{array}{l}\text { Date of first } \\
\text { reported case of } \\
\text { SARS-CoV-2 } \\
\text { infection at the } \\
\text { nursing home }\end{array}$ & $\begin{array}{l}\text { No. of residents } \\
\text { testing positive } \\
\text { for SARS-CoV- } \\
2^{\mathrm{b}, \mathrm{c}}\end{array}$ & $\begin{array}{l}\text { No. of staff } \\
\text { testing } \\
\text { positive for } \\
\text { SARS-CoV- } \\
2^{\text {b,c }}\end{array}$ & $\begin{array}{l}\text { Last SARS-CoV-2 } \\
\text { infection case } \\
\text { documented } \\
\text { among residents or } \\
\text { staff }\end{array}$ & Previous outbreaks \\
\hline A $(103 / 58)$ & $\begin{array}{l}14 \text { October to } 28 \\
\text { December }\end{array}$ & $\begin{array}{l}21 \text { October/29 } \\
\text { October }(4.5)\end{array}$ & 9 November & $1^{\mathrm{d}}$ & - & 9 November & Yes (16 June) \\
\hline A $(103 / 58)$ & $\begin{array}{l}14 \text { October to } 28 \\
\text { December }\end{array}$ & $\begin{array}{l}10 \text { December/28 } \\
\text { December (8.6) }\end{array}$ & 17 December & 25 & 13 & Outbreak ongoing & $\begin{array}{l}\text { Yes ( } 16 \text { June and } 21 \\
\text { October) }\end{array}$ \\
\hline B $(105 / 60)$ & $\begin{array}{l}6 \text { November to } 28 \\
\text { December }\end{array}$ & $\begin{array}{l}6 \text { November/19 } \\
\text { November }(4.5)\end{array}$ & 11 November & - & $1^{\mathrm{e}}$ & 11 November & $\begin{array}{l}\text { Yes ( } 17 \text { June and } 5 \\
\text { October) }\end{array}$ \\
\hline C $(48 / 25)$ & $\begin{array}{l}6 \text { November to } 28 \\
\text { December }\end{array}$ & ND & NR & - & - & - & No \\
\hline D $(101 / 81)$ & $\begin{array}{l}7 \text { October to } 28 \\
\text { December }\end{array}$ & $\begin{array}{l}7 \text { October/12 } \\
\text { November (6.9) }\end{array}$ & $\mathrm{NR}^{\mathrm{f}}$ & - & - & - & Yes (9 July) \\
\hline E $(115 / 85)$ & $\begin{array}{l}7 \text { October to } 28 \\
\text { December }\end{array}$ & $\begin{array}{l}26 \text { October } / 30 \\
\text { October }(8.3)^{g}\end{array}$ & 17 October & 14 & 10 & 16 November & $\begin{array}{l}\text { Yes ( } 17 \text { June and } 13 \\
\text { July) }\end{array}$ \\
\hline
\end{tabular}

ND, not detected; NR, not reported.

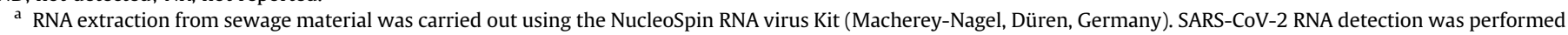

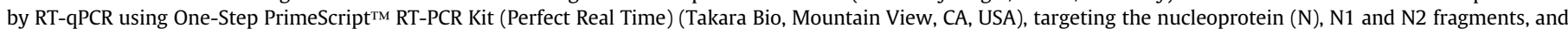

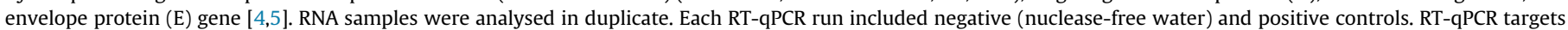

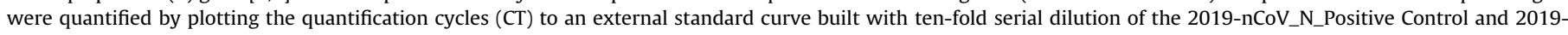
nCoV_E_Positive Control (IDT). Mengovirus RNA recovery rates were calculated and used as quality assurance parameters according to ISO 15216-1:2017.

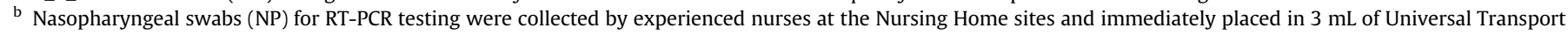

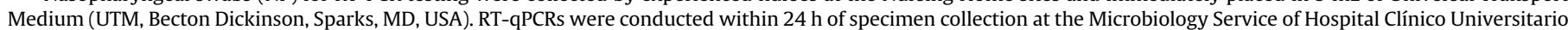

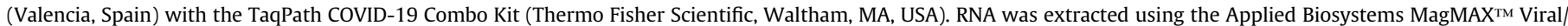
Pathogen II Nucleic Acid Isolation Kits coupled with KingFisher Flex automated instrument (Thermo Fisher Scientific).

c No reinfections were documented among residents and staff.

d Resident tested for SARS-CoV-2 infection because appearance of symptoms compatible with COVID-19 (fever and cough).

e Staff (asymptomatic) tested as a close household contact of a COVID-19 case.

${ }^{\mathrm{f}}$ Residents and Staff members were screened for SARS-CoV-2 infection by RT-PCR on 29 October.

$\mathrm{g}$ Two of the four sewage draining sites were not tested until 26 October.

(Fig. S1). SARS-CoV-2 infection cases among residents or staff, either asymptomatic or symptomatic, were documented in three of the four $\mathrm{NH}(\mathrm{A}, \mathrm{B}, \mathrm{E})$ (Table 1). According to public health policies in place in our Health Department within the study period, systematic testing of residents and staff at $\mathrm{NH}$ A and $\mathrm{NH} \mathrm{E}$ was triggered by the occurrence of symptomatic cases and conducted within $48 \mathrm{~h}$. Index cases were diagnosed within $24 \mathrm{~h}$ after symptom onset. At $\mathrm{NH} \mathrm{B}$, testing of all residents and staff was driven by detection of a single asymptomatic case among staff workers; this individual had been identified as a household contact of a COVID-19 case. In NH B, first detection of SARS-CoV-2 RNA in wastewater occurred approximately 1 month after an outbreak declaration involving three residents, who were promptly isolated following diagnosis, and 5 days before detection of the staff case. Hence, the possibility exists that detection of viral RNA in wastewater resulted from long-term shedding by infected residents.

No cases were identified at $\mathrm{NH}$ D within the study period, despite repeated detection of SARS-CoV-2 RNA in the sewage drain. Of note, as a 'proof of concept' approach, residents and staff at NH D were screened by RT-PCR in nasopharyngeal swabs on 29 October, 12 days after SARS-CoV-2 was first detected in sewage-all yielded negative results. A thorough investigation conducted afterwards revealed the existence of cross-contamination between sewage drains of this $\mathrm{NH}$ and that of an adjacent building that had gone unnoticed. SARS-CoV-2 RNA was not detected in samples collected from $\mathrm{NH} \mathrm{C}$ and no cases were documented throughout the followup period.

Presence of SARS-CoV-2 RNA in sewage preceded identification of isolated cases among residents or staff (in both cases symptomatic) or outbreak declaration in two $\mathrm{NH}$ (NH A on two different occasions, and $\mathrm{NH} \mathrm{B}$ ), with lag times ranging from 5 to 19 days. Interestingly, by using an epidemic transmission model, Kaplan et al. [6] demonstrated that tracking SARS-CoV-2 RNA concentration in sewage sludge provides a 3- to 5-day lead time over tracking hospital admissions.

Repeated detection of SARS-CoV-2 RNA in sewage was not documented until after outbreak declaration in $\mathrm{NH} \mathrm{E}$, although it should be noted that between 7 October and the first case detection on 17 October only two of the four sewage drains at $\mathrm{NH} \mathrm{E}$ had been sampled.

SARS-CoV-2 RNA levels in wastewater samples increased exponentially over the course of $\mathrm{NH}$ outbreaks ( $\mathrm{NH} \mathrm{A}$ and $\mathrm{NH} \mathrm{E}$ ), reaching peak levels above $8.0 \log _{10} \mathrm{GC} / \mathrm{L}$ (see Supplementary material, Fig. S1).

Finally, disappearance of SARS-CoV-2 RNA from sewers was associated with control of outbreaks or absence of new case documentation following implementation of adequate measures (isolation of positive case and quarantining of close contacts) (see Supplementary material, Fig. S1). The SARS-CoV-2 outbreak at NH A was currently still active as of January 12 .

The present study has several limitations that must be acknowledged. First, no sequencing data were available for the clinical and environmental SARS-CoV-2 variants detected, so sequence-matching analyses could not be performed. Second, cell cultures from sewage specimens were not performed.

In conclusion, results from this study suggested that SARS-CoV2 RNA surveillance of sewage drains may serve as an early warning system for isolated cases or outbreak declaration of SARS-CoV-2 infection in NH. Frequent SARS-CoV-2 RT-qPCR sewage testing coupled with targeted screening of residents and staff may prove useful for early blunting of virus transmission and spread at $\mathrm{NH}$. 
Further studies with a larger site sample are warranted to confirm this assumption.

\section{Transparency declaration}

The authors declare that they have no conflicts of interest.

This work received no public or private funds.

\section{Author contributions}

LD, RS, EA and IT contributed to methodology and data validation. LA, RS, JFM, GS and DN contributed to formal analysis. LD, RS, JFM, GS and DN contributed to conceptualization and supervision. PB, MJB, PL-F and RO contributed to the supervision of RT-PCR testing at $\mathrm{NH}$ facilities. $\mathrm{LD}, \mathrm{GS}$ and DN wrote the original draft. All authors reviewed and approved the original draft.

\section{Acknowledgements}

We thank all personnel working in the nursing homes and the Hospital Clínico Universitario of Valencia for their unwavering commitment in the fight against COVID-19.

\section{Appendix A. Supplementary data}

Supplementary data to this article can be found online at https://doi.org/10.1016/j.cmi.2021.02.003.

\section{References}

[1] Grabowski DC, Mor V. Nursing home care in crisis in the wake of COVID-19. JAMA 2020;324:23-4.

[2] Walsh KA, Jordan K, Clyne B, Rohde D, Drummond L, Byrne P, et al. SARS-CoV-2 detection, viral load and infectivity over the course of an infection. J Infect 2020;81:357-71.

[3] Hassard F, Lundy L, Singer AC, Grimsley J, Di Cesare M. Innovation in wastewater near-source tracking for rapid identification of COVID-19 in schools. Lancet Microb 2020. https://doi.org/10.1016/S2666-5247(20) 30193-2.

[4] Randazzo W, Cuevas-Ferrando E, Sanjuán R, Domingo-Calap P, Sánchez G. Metropolitan wastewater analysis for COVID-19 epidemiological surveillance. Int J Hyg Environ Health 2020;230:11362.

[5] Randazzo W, Truchado P, Cuevas-Ferrando E, Simón P, Allende A, Sánchez G. SARS-CoV-2 RNA in wastewater anticipated COVID-19 occurrence in a low prevalence area. Water Res 2020;181:115942.

[6] Kaplan EH, Wang D, Wang M, Malik AA, Zulli A, Peccia J. Aligning SARS-CoV-2 indicators via an epidemic model: application to hospital admissions and RNA detection in sewage sludge. Health Care Manag Sci 2020. epub ahead of print. 